\title{
Political aspects of innovation
}

\author{
Jerry Courvisanos* \\ School of Business and the Centre for Regional Innovation and Competitiveness, University of Ballarat,
} P.O. Box 663, Ballarat, Vic. 3353, Australia

\section{A R T I C L E I N F O}

\section{Article history:}

Received 29 January 2008

Received in revised form 27 March 2009

Accepted 3 April 2009

\section{JEL classification:}

$\mathrm{O} 25$

032

P16

Keywords:

Innovation policy

Innovation management

Political economy

Innovation typology

Kaleckian economics

\section{Introduction}

Innovation has become the quintessential feature of commercial, political, economic, and business development. Thus, public innovation policy has crossed over from being one aspect of industrial policy in the mid-20th Century - through patent rights, government procurement and research and development [R\&D] support (Scherer, 1970, pp. 122-125); to a top national priority in the early 21 st Century - requiring holistic systems review of a country's innovation policy and performance (OECD, 2005). Apart from a systematic review of all member OECD countries' innovation policies, there have been a plethora of government initiatives-national independent reviews (e.g. Cutler Innovation Review in Australia), "green" policy discussion papers (e.g. Growth and Innovation Framework in New Zealand), and "white" paper policy documents (e.g. Science Budget and Innovation Letter in The Netherlands). Given this recent strong political focus on public innovation policy as an economic strategy, there needs to be framework to conduct empirical research and also to design appropriate innovation policies. A political economy framework for innovation does not exist, and this article develops one by applying some fundamental contributions

\footnotetext{
* Tel.: +61 35327 9417; fax: +61353279405.

E-mail address: j.courvisanos@ballarat.edu.au.

URL: http://www.cric.com.au/cb_pages/staff_jerrycourvisanos.php.
}

from a pioneer in political economy, Michał Kalecki (Harcourt, 2006, pp. 160-164).

As a starting point, still the best definition of innovation comes from Joseph Schumpeter, who began the modern-day research into innovation. Schumpeter defined innovation in five forms: (i) new products unfamiliar to consumers, (ii) new methods of production or new ways of handling commodities (processes), (iii) opening up new markets not entered into previously, (iv) new sources of supply of raw materials or half-manufactured goods, and (v) new organisation of the competitive structure of an industry (Schumpeter, 1938, pp. 63-66). ${ }^{1}$ All five forms are transformational as they lead to what Schumpeter called, "creative destruction"-destroying the old forms of accumulation and replacing it with new forms. These transformations work through innovation processes which are bounded by the specific institutions and political frameworks (or political economy) that influence the development of any particular innovation. ${ }^{2}$

\footnotetext{
1 The economics literature generally supports this view of innovation. In the context of the discussion that follows, it is interesting to note that Kalecki (1954, p. 158) identifies innovation with a very similar list of phenomena to that of the five forms by Schumpeter.

2 For example, the innovation path of military technology is heavily circumscribed by the particular needs of warfare, from Spartan hoplite to USA stealth bombers. Jones (1987) explains these processes.
} 
How is innovation to thrive? O'Hara (2007, p. 15) recognises in the context of political economy that there is the innovation-competition dialectic that provides the dynamic force for innovation. The competitive search for profits brings forth innovation (or creative destruction) within the environment of instability and uncertainty inherent in all market systems. If innovation is not strong enough, accumulation (or physical investment) will falter due to declining monopoly rents from the innovation. If competition is too strong, the monopoly profits become quickly dissipated so that adequate rates of return are not realised. This also threatens accumulation. The task of political economy is to understand how capitalism stays within these narrow boundaries in order to operate and then develop innovation policies that encourage and support accumulation for all the five Schumpeterian forms of transformational innovation.

Public and private institutions (conventions, rules, routines) exist to allow the system to continue to replicate itself. There are specific interventions into the innovation-competitive dialectic to ensure the narrow boundaries are maintained for the continuation of innovation. Such intervention can be either commercial (e.g. Bill Gates monopolising information technology) or political (e.g. warfare needs for military technology). A political economy framework for innovation needs to critique the current situation in innovation performance and then to devise policy-induced interventions that serve the best interests of the broader community and not purely the narrow interests of some powerful commercial organisations and their political supporters. This will help to sustain the system within a certain politically acceptable range of inequality and instability.

Innovation performance is not easy to measure. For the OECD to measure innovation in their reviews of member countries, Aubert (2006) developed a list of 17 indicators for the effectiveness of a nation's innovation system. This long list has input indicators like business expenditure on R\&D per capita and government effectiveness, to output indicators like patent applications and productivity growth. A "scorecard wheel" is then drawn to make comparisons between countries. From a political economy perspective, the OECD identifies such innovation performance as being influenced by four major criteria of the national innovation system: (i) framework conditions for innovation arising out of the nation's regulations, customs and rules; (ii) governance of the innovation system through public planning, funding and cooperative linkages; (iii) competitive university-based research funding and training, and (iv) promotion of innovation within firms and across the business sector through supply-based competence measures and demand-based procurement measures (OECD, 2006, pp. 7-8). This OECD innovation review agenda provides the background to the critical framework developed below.

Section 2 outlines the role of innovation based on Schumpeter's long-run perspective, and then incorporates the cycle and trend perspective of Michał Kalecki. This allows the introduction of the role of government in Section 3 via an approach to political economy devised by Kalecki for employment policy. Section 4 adopts this approach to develop a framework for critiquing the strategy of public innovation policy in general. Political economy implications for innovation policy are then derived in Section 5 , followed by a short conclusion.

\section{Cycle and trend: role of innovation in Schumpeter and Kalecki}

Schumpeter is recognised as the economist who put innovation into the centre of the economic process and inspired the recent large impressive research agenda of neo-Schumpeterian evolutionary economics (see Malerbo and Orsenigo, 1997). Schumpeter (1939) is a massive two-volume thesis on the processes of innovation and their absorption into the capitalist business cycle mechanism. For Schumpeter, this mechanism is a complex interaction between three classes of cycles. Major innovations initiate long wave (Kondratieff) cycles in which the boom develops from thorough far-reaching changes of the "technology system" (Freeman and Perez, 1988, p. 46). The roughly 10 -year Juglar investment cycles provide the accumulation of capital stock to impel technology systems forward. Schumpeter saw the trend of Juglars forming the long waves, with a strong accumulation process carrying the technology system on the upswing of the long wave. The roughly 40-month inventory (Kitchin) cycles reflect demand for the end products and whose trend forms the Juglars. Coincident trough in all three cycles results in deep recessions. In essence, Schumpeter argues that there would be no business cycles with deep recessions if not for the clustering of innovations around technology systems that leads to bunching of investment in order to implement (or commercialise) these innovations.

Rothbarth (1942), in his review of Schumpeter (1939), rejects the strict procedural linkage between innovation and investment, but appreciates that uncertainty created by the innovation process leads to strong dependence of physical investment (whether by equity funds or by leverage with debt funds) on current profits. To Rothbarth, it is this argument which connects Schumpeter to the work of Kalecki. Synthesis between Schumpeter and Kalecki, identified by Rothbarth, provides the starting point for examining the role of innovation in Kalecki. Rothbarth (1942, p. 227) argues that the profit link to investment, so crucial in all of Kalecki's work, is the "adaptation mechanism" that enables the bunching of investment (in Juglars) behind some long-run innovation "impulse". This turns Schumpeter's long-run supply-side process into one that is centred on effective demand. Thus, the influence of effective demand is based on the speed and strength of diffusion of innovation as determined by the ability of firms to invest in innovation out of profits. Time lags in investment are crucial in the innovation process, as Kalecki emphasises but Schumpeter rejects.

Rothbarth's assessment of Kalecki's work was based on the complete re-investment of profits in Version I of Kalecki's business cycle model from the 1930s. This was only the beginning of a major lifelong investigation into cycles and growth. In this version, a dampened cycle results with growth coming from exogenous shocks. Cycle Version II in the 1940s introduced semi-autonomous development factors, notably innovation, to “...engender a longrun upward trend" (Kalecki, 1954, p. 151). Finally (2 years before his death) in Kalecki (1968), cycle Version III makes innovation specifically endogenous to the investment process, thus integrating the cyclical short-term with the long-run growth trend. Thus, the trend and cycle should not be considered separately. For this final version, inventions that are commercialised through investment “... .add to profit expectations over and above those generated by the movement of demand in the course of the cycle" (White, 1999, p. 347), leading to a cumulative process of cyclical growth. ${ }^{3}$ White (1999) identifies two reasons in Kalecki (1968) to account for this. One is increased productivity in the form of process innovation that incorporates technical progress in new capital equipment, making the

\footnotetext{
${ }^{3}$ Goodwin (1967) independently developed a similar model of cyclical growth and developed this further along Kaleckian lines in Goodwin (1990, p. 99) with the search for ever-renewed profit through technical change as the innovation impetus at the investment cycle trough. Goodwin (1987, p. 106) explains that "growth generates cycles and...cycles interrupt growth. Such was the view of Marx, a view that was absorbed and elaborated by Schumpeter, but has remained peripheral to mainstream economics". The innovation-instigated cyclical growth process is based on Marx's law of capitalist accumulation (Marx, 1954, p. 574), which "provided inspiration to contemporary writers, in particular Kalecki and Goodwin" (Medio, 1987, p. 667).
} 
previous capital stock technologically obsolete. ${ }^{4}$ The other is product innovation coming from the stimulus to investment arising from entrepreneurs wanting to be the "... first to avail themselves of the technical novelties" and thus adding a new level of demand (Kalecki, 1968, p. 269). ${ }^{5}$

At this point of the analysis when effective demand has been clearly established in the innovation process, Kalecki's approach can be linked back to Schumpeter. White (1999, p. 350) recognises “...the stream of inventions underlying the process of innovation could be sufficiently erratic to provide the irregularity in economic behaviour necessary to produce deviations in demand and output from those anticipated by producers." With the diffusion of successful innovations, Courvisanos (1996, pp. 114-139) shows that these deviations can be seen as triggers for cyclical investment turnarounds in periods when commitment of orders to investment is highly susceptible, either as too high (over commitment at expansion peak) or too low (under commitment at contraction trough). There can be reinforcement of this process by the inventory mechanism, in that any small upswing of an inventory cycle at the trough of a business (or Juglar) cycle provides a favourable climate for the spread of investment embodying innovation. This is particularly helpful for explaining the most difficult aspect of any cycle, the rise out of a contraction. In this respect bunching of investment occurs as per Kalecki, with the stimulus from clusters of 'basic' innovations as per Schumpeter. ${ }^{6}$

From the effective demand perspective, it is the accumulation process which forms a chain of short period situations that determines the long-run economic growth path (Kalecki, 1971, p. 165). In support of this perspective, Lowe (1976, p. 10) explains that the long-run "secular process is, in fact, an abstraction derived from a sequence of short-term movements, the latter being the only 'real' processes". Courvisanos (1996, pp. 156-159) specifies how the accumulation process, stimulated by innovation, unfurls a long wave trend line out of the short-term investment cycle whilst impacting on profit returns at the margin. The susceptibility concept of tension felt by entrepreneurs in relation to their fragile confidence is the mechanism that drives accumulation in innovation and provides the link from short-term business cycles to long waves. A "constellation" of successful incremental and radical innovations that cluster together, applying new basic scientific principles (Freeman and Perez, 1988, pp. 4607), ameliorates the susceptibility of entrepreneur-owners to accumulation, providing strong investment expansions and pushing up the long-run trend of economic activity. ${ }^{7}$ On the other hand, monopoly control of technology systems by relatively conservative entrepreneur-managers intensifies susceptibility to provide less

\footnotetext{
${ }^{4}$ Salter (1966) developed this aspect of process innovation that has been the basis of much research work in the area of obsolescence (see Bloch et al., 2007).

5 White (1999, p. 350) identifies a third reason from a Sraffian perspective. This is the stimulus to investment "arising from changes in relative profit rates as a result of changes in technology."

${ }^{6}$ Empirical work by Courvisanos and Verspagen (2002) using long run patent data supports bunching effect of investment (á la Kalecki) while identifying the clustering of innovation (á la Schumpeter). This is in contradistinction to Silverberg and Verspagen (2003) who find no clustering of basic innovations. This implies that one basic innovation leads to a cluster of incremental innovations in support of the one basic technology system (Perez, 2002, p. 27). All this cluster cycle research is distinctly different from the neoclassical real business cycle research agenda in which clusters occur only due to expectational errors as deviations from the natural (equilibrium) rate, and which Zarnowitz (1985) surveyed as empirically inadequate in explaining business cycles.

As Courvisanos (1996, p. 109) elaborates: “... strong growth in aggregate investment due to new technology, if diffused quickly into a particular industry, would produce large amplitudes in firm investment expansions and small amplitudes in firm investment contractions. This then produces an upward investment growth trend quicker and stronger than in industries where adaptation to the new paradigm is slower."
}

potent expansions and possibly even reducing the long-run path of economic activity.

Effective demand also has important consequences in terms of the innovative potential of an economy. Demand-pull innovation theorists, led by Kaldor (1966) at the macroeconomic level and Schmookler (1966) at the microeconomic level, have produced a plethora of studies identifying the causal sequence from scale economies achieved through expanded demand that increase the rate of investment and thus determine the rate of innovation. ${ }^{8}$ Fontana and Guerzoni (2008) distinguish between the Schmookler market size demand-pull hypothesis that induces primarily process innovation and the Myers and Marquis (1969) user-led demand-pull hypothesis popularised by von Hippel (2005) which induces chiefly product innovation. Kalecki clearly recognises this sequence, despite having identified the innovation-driven process. Kalecki places demand-pull innovation into an appropriate effective demand context by viewing both hypotheses as "part and parcel of 'ordinary' investment” demand (Kalecki, 1954, p. 158). This occurs, for example, when there is R\&D investment by large firms stimulated by strong sales or investment in the user industry, both demand-inducing innovations evidenced through intellectual property rights. Courvisanos (1996, p. 42) calls this "endogenous" innovation.

Within this innovation-investment Kaleckian process is the basic model for cycles and trend of a capitalist economy with no state apparatus. Governments, by becoming heavily involved in innovation and investment policies add a political economy element to this cycle and trend which Kalecki did not explicitly develop. However, there is a political economy model that Kalecki developed in relation to employment policy and its impact on cycle and trend. The next section outlines this model.

\section{Kalecki's political aspects of full employment}

What does "political aspects" mean in terms of economics? Let us first examine it from the perspective that Kalecki wrote about it in 1943 in the context of the Great Depression experienced through the 1930s. In his extensively quoted article, Political Aspects of Full Employment [PAFE] (1943), Kalecki developed a Marxian class analysis where the capitalist class prevails over the political institutions of society.

Kalecki identified various political 'stop-go' actions operating over the period of a business cycle. That is why this analysis has been dubbed "political business cycles". Profits begin to be squeezed at the top of the boom as consumption spending slows down. Capitalist entrepreneurs have the exclusive control of accumulation, and under these profit squeeze conditions they make the decision to reduce their investment spending, which turns the pure capitalist business cycle into a contraction phase. Keynesian macroeconomic policies provide the method by which this contraction can be prevented and full employment maintained. This is through stimulation of effective demand via raising government spending, reducing taxes and lowering interest rates (with increased money supply). These three policy instruments can be employed to affect an expansionary impact on the economy. This policy troika again has been implemented in the aftermath of the 2008 Global Financial Crisis [GFC].

Keynes (1936) expressed faith that the power of his effective demand idea will be used to stabilise the business cycle at full

\footnotetext{
${ }^{8}$ Kleinknecht and Verspagen (1990) use Schmookler's cross-sectional dataset to support the hypothesis that market size influences innovative activity, but also raise empirical issues of mutual dependence of demand and innovation. To counter these problems, Pavi and Vivarelli (2007) use time series data to empirically show that demand-pull is important at macroeconomic, sectoral and firm levels.
} 
employment. Osiatyński (1990); Kalecki (1943) also recognised the powerful tool of effective demand management by government (since he developed this same analysis in 1933), but he also recognised the stronger power of business interests to prevent this from occurring. Kalecki specified three fears that capitalists have with Keynesian full employment: (i) Loss of economic control when demand management policies aim for stability, thus effectively depriving capitalists of both their power to influence economic conditions though their investment decisions and also their power to influence governments themselves. (ii) Loss of policy control as governments extend their impact through their own investment spending into areas regarded as business's legitimate sphere of influence (e.g. transport, public utilities). (iii) Loss of industrial control of the workforce if governments are able to maintain full employment over the long-run, so that 'the sack' ceases to play its disciplinary role for businesses.

Applying these three fears, a political business cycle $[\mathrm{PBC}]$ emerges. Towards the top of the expansion phase of the cycle, the combination of profit squeeze and inflationary pressures manifests itself in a significant negative shift in the state of business confidence. This is reflected in profit rates falling, financial gearing rising and capacity utilisation falling as large capital investment projects come on stream at the time when consumption rates are slowing down (Courvisanos, 1996). Business interests enlist rentier interests to support them in having mainstream economists identify the economy as "unsound" (Kalecki, 1971, p. 144). Pressure is placed on governments to renege on full employment commitments and introduce the 'stop' elements of fine-tuning by using policy instruments to dampen effective demand. This ensures the demise of old capital stock and the reduction in real wages, essential in the renewal of capitalism.

The 'go' policy elements of government stimulation in effective demand are then used when business interests enlist workers to support them in having mainstream economists declare a slump as detrimental to the economy. There would, however, be strong debate between all these supporters of stimulation as to the precise instruments and extent of their use. A stimulation package allows the cycle to move into a new expansionary phase, with new capital stock coming forward on the basis of innovation in newer technological developments. Old capital stock can then be decommissioned so that utilisation rates are manageable in relation to new investment spending (Galbraith and Darity, 1994, pp. 459-468). Kennedy (1973) provides empirical support in the U.K. (1953-1971) for a "predominantly" planned 'stop-go' policy approach, with technical errors due to poor forecasting playing only a relatively minor role.

Bhaduri and Steindl (1983), Catley and McFarlane (1981) and Steindl (1979) use PAFE to explain the long-run implications of the $\mathrm{PBC}$ in terms of a 'political trend'. These studies draw on the historical developments in advanced capitalist economies to show that the shift in economic policies in the early 1970s from Keynesian 'stopgo' policies to Friedman's monetarism and neoliberalism is due to the same three fears Kalecki identified in PAFE. The difference is that in this version of the class-based $\mathrm{PBC}$ a longer timeframe allows what Mair and Laramie (2002) refer to as "...feedbacks between capitalists and workers over the political and social tensions of full employment to work themselves through." These feedback effects generate rent-seeking behaviour by powerful monopoly control interests who form 'distributional coalitions' to shift profit shares upwards by establishing obstacles in the road to full employment. These coalitions reduce efficiency and depress the adoption of new technologies in an effort to skew the income shares. Mair and Laramie (2002) provides empirical evidence to reveal the end of the post-war 'full employment' stop-go strategy in the early 1970s coincided with the only significant period of income share turbulence. Aschauer (2000) sets out empirical evidence for the USA that sup- ports this contractionary political trend with the decline of public investment since the early 1970s. Catley and McFarlane (1981) and Otto and Voss (1994) are two studies that provide similar historical evidence for Australia.

The contractionary political trend enabled the capitalist class to assert its economic and social dominance over labour and to cleanse capital of inefficient and oversupplied old stock. This process varies in time over different economies, with the USA leading the way after the 1990-1992 recession into a new age of active innovation, stimulating large private investment spending and generating a new expansionary political trend. This expansionary trend consists of a new dynamic in public policy governance that has a PBC perspective as governments support rearmament (and war), tax cuts for the rich, innovation-supported subsidies and allowances, and 'cheap money' in a fragile financial system. Kalecki (1945) identified these stimulatory policies which have been reactivated by the USA at the start of the 21st Century.

PAFE raises in policy terms what Harcourt (2006, p.147) calls the "Kaleckian dilemma". As economists, Keynes and Kalecki both provided the policy tools and techniques that have the potential to ensure full employment, even with rising inflation concerns as the economy reaches towards full capacity. Both recognised this inflation threat and developed approaches to manage it. Yet, from a political economy perspective, Kalecki recognised that full employment is unattainable. Having a Marxist perspective, he accepted this dilemma as inevitable since it exists because of the contradictions of capitalism itself.

\section{Political aspects of innovation}

In this section, the PAFE approach is appropriated to critique the process of public innovation policy-making. Whereas above in the $\mathrm{PBC}$ story innovation played only a minor role, in this section innovation is the central character around which policy revolves. Immediately after World War II [WWII] all the developed economies pledged allegiance to attainment and maintenance of full employment as the panacea for the inherent crises of capitalism. This approach was rejected in the 1970s, with emergence of the contractionary political trend as described in the previous section. This, however, raised a significant concern as there was no full employment public policy geared to providing the stimulus of innovation out of troughs in the business cycle. The policy framework thus became one that was more closely related to Kalecki (1945), with government policy aiming to stimulate private investment and innovation that is supported by new capital equipment.

Innovation is incorporated into investment theory as innovation alters the incentive to invest by changing the cost of production or altering product demand to raise profitability. Osiatyński (1991); Kalecki (1968) and Laramie and Mair (2007) both imply technical progress in their investment function specifications but only indirectly, the former by theory and the latter by empirical estimation. Salter (1966) links the inducement to invest to new technology by utilising a vintage capital model in which innovation is embodied in capital equipment. Thus, governments have developed innovation policies aimed at stimulating investment with innovation, which Porter (1990) has seen as crucial in building a nation's competitive advantage. Such policies work through various approaches like rearmament, R\&D subsidies, technology park infrastructure like incubators, tax credits, and supportive income tax cuts for the higher income groups. This shift from direct employment policies to stimulating investment policies is exemplified by the reduction in emphasis on tariff protection policies aimed at supporting employment in protected industries. Tariffs have been replaced by innovation policies which aim to guide and support transformation of the economy into a new technological age, while employment is 
seen in the role of a useful spillover (or externality) to the technological imperative.

The 'political aspects of innovation' [PAI] can be identified in all periods of capitalism, but it took on a much more significant role with the shift from protection to innovation. Conforming to PAFE, the PAI approach identifies three fears that capitalists have with robust innovation: (i) Loss of economic control with respect to their individual market power as innovation encourages new entrants that have the potential to reduce the incumbents' market share and ability to control the market. Along with this comes the fear of the lack of adequate financial capital to support incumbents' innovations. Governments have various innovation policies to support the incumbents; notably, R\&D subsidies and tax concessions for incremental innovations, patent protection and other intellectual property rights [IPR]. ${ }^{9}$ (ii) Loss of policy control as innovation becomes distributed across society through the public institutions and public infrastructure that create the national innovation system. Governments have developed various strategies that support incumbents to regain some policy control, notably deregulation, privatisation, public-private infrastructure programs and public contracting. ${ }^{10}$ (iii) Loss of industrial control of the workforce if governments maintain industrial relations policies that reflect the full employment-type high-union membership structure of the first 20 years after WWII. Governments have introduced new industrial relations policies aimed at supporting and encouraging 'flexibility' in the workplace in the name of innovation. This flexibility relates to the ability of firms to lower labour cost and structures which reduce marginal costs of old technologies, delaying introduction of new product and process innovations. ${ }^{11}$

As with PAFE, PAI is a class-based approach that can be applied as a PBC. Towards the top of the expansion phase of the business cycle, the negative shift in the state of business confidence identified above has implications for innovation. Incremental innovation is strongly working through all the industry sectors in order to reinforce benefits of prior significant innovation with minimal new investment. Pressure is placed on governments to underpin minor innovation by increasing their efforts to ensure minimising capitalists' loss of economic, policy and industrial power. Strengthening policies (and more effectively enforcing existing policies) that support incremental innovation can be applied in a boom period with minimal negative political repercussions. Such policies include increased privatisation of established areas of the public sector with easily available funding; stronger pro-business industrial relations with increased efforts to lower wages and thus retain old technology; greater IPR support for established large companies emboldening them against increased competition from new small entrepreneurial players. All such actions undermine 'true' transformational innovation and encourage 'spin-doctoring' by powerful commercial organisations. This ensures the sedation of radical innovation, preventing stimulation of new activity during the cyclical expansion. Renewal is delayed.

The delay in transformational innovation means that financial resources are siphoned away to create financial bubbles. This "bubble mania" has been identified in two different decoupling mechanisms that separate the real and financial economic sectors. Both mechanisms are influenced by Schumpeter's recognition that the roles of entrepreneur and financier as interdependent (Schumpeter, 1939, p. 104). Perez (2002) identifies the first "bubble mania" as a hiatus between installation and deployment of new technology. This is a period when the new technology is exploited in a reckless frenzy of "irrational exuberance" for capital gains on

\footnotetext{
${ }^{9}$ For evidence of this, see Perez (2002).

10 For evidence of this, see Patel and Pavitt (2000).

11 For evidence of this, see Harcourt (1997).
}

any business plan that has a link to the newly installed technology (e.g. 1840s USA railway boom and the late 1990s global dot.com craze). Perez sees this period as an inevitable delay in the ubiquitous deployment of the new technology. In terms of Kalecki's PBC, government innovation policy support through the boom for the newly established capitalists, along the lines of the PAI model, sows the seeds of the cyclical contraction that follows the inexorable bursting of the bubble. The trend of the cycle remains on the upward part of the long wave as this contraction is only a hiatus in the unfolding technological trajectory (or diffusion) of the new technology system (e.g. information and telecommunications in the post-WWII period; Freeman and Perez, 1988, p. 53).

Minsky (1982) identifies the second "bubble mania" that follows the maturity of the new technology, as financiers search for alternative highly speculative (or "Ponzi") schemes. As the PAI model explains the continued public innovation support for mature technology, then significant installation of radical innovation in new technology systems is delayed. Despite expansionary monetary policy to ameliorate the previous "installation" contraction, government support for mature industries makes financiers wary of investing in new basic innovations (e.g. green innovations in the early 2000s), and instead support "old" technologies (e.g. petrolguzzling automobiles in the early 2000s) which augment excess capacity already building up in the latter. Mature industries will not be able to soak up the available funds, so another round of Ponzi financing develops around financial assets (e.g. sub-prime mortgages and collateralised debt obligations in the early 2000s). Again, Kalecki's PBC operates as governments' PAI approach provides the deregulatory space and financial wherewithal for non-productive financial innovations (Kregel, 2008). This bubble sows the seeds of the "deployment" contraction and further delaying the deep installation of new technology systems, with monopoly capital arguing that the economy cannot afford governments providing support and stimulus to new, untried and expensive activities like climate change based eco-innovations. The trend of the cycle is more problematic in this contraction, with the depth of the contraction impacting on the long wave trend downwards (e.g. electrical and heavy engineering in the Great Depression; Freeman and Perez, 1988, p. 51).

When the business cycle is well into contraction, the circumstances for innovation substantial alter. Limited new capital investment during the downturn from peak activity results in very little innovation. This is despite much $R \& D$ and patenting still going on. ${ }^{12}$ There is a large corpus of knowledge that is not being commercialised, with attendant concerns that rates of return are falling from old capital stock. As some companies fail to sustain themselves through the contraction, the remaining firms begin to feel the pressure of potential new entrants eager to test themselves in the market that has been comatosed. Support for government stimulation in effective demand by economists and business commentators manifests itself by significant initiatives in the area of innovation policy. Strong debate on the nature and extent of this innovation-based stimulation will result in some form of stimulatory package (but within institutional constraints such as the contractionary 'political trend' identified earlier). Eventually new capital stock will come forward on the basis of transformational innovation incorporating newer technological developments.

\footnotetext{
$12 \mathrm{R} \& \mathrm{D}$ expenditure is pro-cyclical in research based (e.g. pharmaceuticals) and high-tech service based industries, as firms in these industries view R\&D as capital investment. Nevertheless, a large absolute amount of R\&D would still go on during contractions. All other industries tend to have constant R\&D expenditure over the business cycle due to the relatively small proportion R\&D compared to total firm expenditure (see Courvisanos, 2007).
} 
The PAI framework enables the tracking of innovation over the period of a business cycle, and identifying the role government policy plays in innovation within the context of the cycle. This framework can be used to evaluate the policy situation in a country, region or specific industry. In the process, another version of the Kaleckian dilemma arises. Governments in advanced developed economies have the policy tools and techniques to encourage and support innovation as a driver of ecologically sustainable development [ESD] during long periods of economic growth (see Courvisanos, 2005). From the private sector, strong profits and consumer demand could promote what can be identified as transformative innovation, redirecting the trajectory of economic development towards ESD. Yet the dilemma from the PAI perspective is that this form of radical innovation is highly unlikely. PAI sees the encouragement of marketing-based incremental innovation during the boom. This can be identified as evasive innovation in pursuit of a traditional economic development growth path by externalising environmental and other negative spillovers. The economic prosperity of the boom brings with it strong profits and rising economic wealth that should support ecologically sustainable innovation, yet the political economy rationale explains why during a long economic boom a shift to this particular form of transformative innovation is highly unlikely.

A current political economy example can be cited to bear out this ESD Kaleckian dilemma. As at November 2007, the national governments of both Australia and the USA had a long-standing objection to ratifying the Kyoto Protocol on greenhouse emission targets. It is interesting to note that USA is the absolute leader in greenhouse emissions, while Australia is the per capita leader. Both see the economic interests of powerful incumbent corporations as being much more important than greenhouse warming and the consequent ecological destruction. This encourages the continuation of incremental evasive innovation that has only marginal benefits to the ecology but maximum benefit to incumbent enterprises, while ignoring the massive potential ecological (and national economic) benefits accruing from a transformative pro-ecology innovation trajectory. ${ }^{13}$

\section{Political economy implications for innovation policy}

With developed economies accepting the Kaleckian contractionary political trend since the mid-1970s, governments have restricted severely their expansionary spending policies. For legitimation with the voting public, governments devised an alternative strategy for encouraging employment. This alternative pro-business strategy was described in the PAFE section as supporting rearmament and war, tax cuts, R\&D and entrepreneurship, and lenient lending. The aim of this strategy has been to support directly the capitalist accumulation process through (respectively) defence contracts, private spending, technological change, and private finance. Innovation and private investment are the expected outcomes of this strategy. The USA was at the forefront of this strategy. Reagan's StarWars project and the two Bush Iraq wars led the armaments spending, while a shift to small business development by President Clinton was reinforced by President G.W. Bush. $^{14}$

\footnotetext{
13 In Australia, the election in December 2007 of the slightly left leaning Labor Party on an electoral promise to ratify Kyoto has ended this unyielding position. In the USA, the presidential election of President B. Obama in November 2008 also had a similar effect. Discussion of these events would take the analysis out of political economy and into the adjoining field of political science.

14 "70 per cent of the new jobs in America are created by small businesses. I understand that. And I have promoted during the course of the last four years one of the most aggressive, pro-entrepreneur, small business policies... And so in a new term, we will make sure the tax relief continues to be robust for our small businesses."
}

The actual outcome of this pro-business strategy is mixed. There have been innovation and jobs growth trends in developed economies with varying degrees of success, but most particularly in USA, Australia and Ireland. This success has been on the back of the boom in diffusion of information and telecommunications [IT] general purpose technologies (Perez, 2002) and massive growth in the Chinese and Indian economies taking advantage of the hardware and software IT elements respectively (Arora et al., 2001; OECD, 2008). Neither came from this pro-business strategy, but more fundamental world developments in computers followed by Indian and Chinese versions of socialism that were set in train during and immediately after WWII. On the negative side, Osiatyński (1997); Kalecki $(1955,1967)$ clearly identifies the wealth gains of armaments-based industries with a high social cost related to inequality, corruption, unproductive ends, and entrenched monopoly power. Parker (2001, p. 382) also exposes the myth of the entrepreneurial economy, in that much of the small business growth is “. . . attributable to 'push factors' including to outsourcing and downsizing by large firms and the changing sectoral composition of employment, rather than 'pull factors' associated with the superior dynamism of small firms." Sylos-Labini (1992) notes the complementarity of small firms to large firms through vertical sequence and horizontal cooperation, ensuring that successful small firms are often symbiotically lock-step dependent on the industry that is dominated by the related large firms. Finally, Davis et al. (1996) present longitudinal data on USA manufacturing to show that small firms exhibit high job destruction rates as well as high job creation rates, with no significant net jobs growth; but with higher uncertain career prospects and lower pay and conditions for their employees.

Examining the business cycle itself, a boom generally leads to the sedation of radical innovation as previously small firms are growing through incremental improvement of their idea and larger firms attempt to defend their market position through minimal marketing-based and evasive innovation. In this situation, both small and large firms are carrying out innovation through rentseeking behaviour with the assistance of government tax cuts and incentives, as well as the provision of subsidies and the enforcing of IPR (Stilwell, 2002, p. 225). In a cyclical contraction, many small firms disappear, while large firms attempt to reconstruct their highly indebted balance sheets without going bankrupt. In such circumstances there is less rent-seeking behaviour, but also very limited opportunities to take advantage of the innovation policies on offer. It is at the trough of the cycle that innovation policy is taken up for genuine creative opportunities by risk-taking entrepreneurmanagers. The problem is that tangible benefit from innovation policy occurs only during the occasional deep trough of the business cycle. Genuine radical innovation that can be transformative is highly constrained.

The PBC approach to innovation described above provides an appreciation of the dynamics of innovation encouragement and enhancement, as it is restricted within the boundaries specified by O'Hara (2007) in the innovation-competition dialectic. Only within these boundaries is the accumulation process viable. In a boom, strong competition and minor incremental innovation lead to quick dissipation of any monopoly rents. In a trough, innovation is tentative with great uncertainty about monopoly rents, and if the innovation is very successful, innovative firms need to work hard to prevent dissipation of monopoly rents. Across this dialectic spectrum, firms use public innovation policies to sustain their monopoly rents. Viable capitalism operates within the narrow boundaries of this spectrum, but this narrowness also severely limits the ability

(President G.W. Bush, Press Conference 4 November 2004; as quoted in Audretsch, 2006, p. xviii). 
of innovation policies to 'make a difference'. The aim of effective innovation policy planning should be to extend the boundaries of operation in the context of this dialectic without threatening the economy's accumulation process.

The cycle and trend patterns deduced from the PAI-based framework are general. This framework needs to be specified in particular economies, but to do this the culture and political system of an economy needs to be clearly delineated. Brown and Ulijn (2004) bring together a set of studies that show the interaction of innovation and entrepreneurship with specific national, professional and corporate cultural dimensions produces various patterns of innovation which, nevertheless, have commonalities. Thus, each economy portrays the dynamics of innovation differently. Each is but a variation on the theme of the political economy innovation aspects identified above.

The politico-economic models by Frey (1978) can be used to identify themes around a group of economies that share important cultural and institutional elements. ${ }^{15}$ The English-speaking nations are influenced most strongly by the market-oriented contractionary 'political trend' that has penetrated all economies that operate within global markets. Scandinavian nations, China, India, Japan and other robust Asian economies have a relatively stronger commitment to public policy proactive intervention. Mid-European nations like Germany, The Netherlands and France place more emphasis on economic stabilising elements based around European Union commitments and accords, but with some specific proactive public policies. Southern European and South American nations have significantly less sophisticated economic and political institutions that have a mixture of all the above, but with strong personality-based parochialism. Within this broadbrush representation there are differences. For example, both Singapore and Malaysia set out to develop a biotechnology innovation cluster, yet only the former has been able to build "...a significant hub of activity." (McColl, 2007, p. 16) Also, Eastern Europe failed to sustain any innovation activity through its communist period despite much R\&D spending and proactive planning. On the other hand, in strong capitalist economies firms with monopoly power stymie innovation by locking-in technologies while exhibiting strong rent-seeking behaviour (Stark, 2001).

\section{Conclusion}

Innovation is transformational (in process) and economic (in outcome). The political dimension casts a large shadow over both process and outcome. The class-based approach outlined in this paper identifies the capitalist elements that drive innovation from within its own reproduction system and the public support that ensures susceptibility to future risk is ameliorated. All this occurs within the context of the boom and bust of business cycles, for it is these short-term economic forces that influence the shape and form of innovation. Forces, both public and private, that are aimed at ameliorating susceptibility to the three fears that capitalists have over the cycle (i.e. loss of economic, policy and industrial control) are the basic dynamic of the innovation process.

The 2008 GFC had its financial roots in Ponzi financing using sub-prime mortgages and collateralised debt obligations in the USA
(Kregel, 2008). However, the economic roots of the GFC go deep into the global innovation process over a much longer time period. The seeds of what the IMF in 2009 called "Great Recession", hark back to the antecedents of the 2000-2001 "installation" contraction of the IT technology system. The dot.com bubble is an example of the (irrational?) exuberance of a youthful innovation that extended past its margin of safety. Fears of monopoly capital abounded prior to the bubble bursting: Loss of economic and financial control of the system to small dot.com entrepreneurs, loss of policy control as the IT system became distributed widely, and loss of industrial control under innovation-generated full employment. Monopoly capital and its government supporters regained the initiative in the contraction, leading to innovation policies and practices that brought the technology system back within its "cushion of safety" (Kregel, 2008). Monetary authorities also increased global liquidity to "soften" the contraction.

Deployment period of the IT system created another strong growth phase-but not the "synergistic growth [with] a new regulatory framework" that Perez (2002, p. 167) was hoping for. Instead, the IT system with excess funds enabled another Ponzi bubble to arise, supported by huge consumer debt and eventually massive inventories of every form of consumer product from houses and cars to microelectronics. Susceptibility to the three fears again emerged, but this time not to a youthful part of the IT sector, but to monopoly capital that underwrote the whole consumerist culture developed in advanced capitalist economies. IT-based innovation to support financially and ecologically unsustainable consumerism has again pushed the global economy past its margins of safety. ${ }^{16}$

Kalecki's political economy approach based on the PAI model can be applied to innovation (including R\&D). With this approach a conjectural economic history of an economy or industry could be used to reveal how innovation policies impact through the course of a business cycle and the consequence this has for long-run development of the innovation(s). ${ }^{17}$ From such an analysis, economic policy for innovation and R\&D support can be understood which could then be used either as a critical realist examination of innovation policy in capitalism or as a pragmatist approach to more coherent innovation policy.

\section{Acknowledgements}

I appreciate the support and hospitality of the Centre for Strategic Economic Studies (CSES), Victoria University, Melbourne, Australia, whilst on professional development leave. The research facilities and staff of CSES have been most helpful during the development and writing of this paper. For comments on earlier drafts of this paper, thanks go to Stefan Kesting (Auckland University of Technology), Colin Richardson (Imperial College London) and participants of two conferences: the 19th Annual Meeting on SocioEconomics Society for the Advancement of Socio-Economics (SASE), Copenhagen June 2007; and the 6th Australian Society of Heterodox Economists Conference (SHE), Sydney, December 2007. I am indebted to three anonymous referees for valuable comments; however, the author alone is responsible for any controversial opinions or remaining errors.

\footnotetext{
${ }^{15}$ A large body of comparative capitalism literature emerged in the mid-1990s aiming to understand the institutional foundations of diverse national varieties of capitalism (see Deeg and Jackson, 2007). The best-known framework by Hall and Soskice (2001) is relevant because it is firm-centred, but it is limited by having only two varieties. Frey (1978), in contrast, has a more diverse typology. For this paper it is adequate to note that the PAI analysis would have to be different in discrete varieties of capitalism.
}

\footnotetext{
16 The story of the 2008 GFC and innovation deserves a research monograph of its own. Suffice here to outline the broad parameters of this story to show its applicability to the PAI approach.

${ }_{17}$ Two historical country case studies are currently being researched by a study team using this PAI approach to public innovation policy. Both are on innovation in the dairy industry-in the two countries with comparative and competitive advantage in dairy: New Zealand and Australia.
} 


\section{References}

Arora, A., Arunachalam, V.S., Asundi, J., Fernandes, R., 2001. The Indian software services industry. Research Policy 30 (8), 1267-1287.

Aschauer, D.A., 2000. Do states optimize? Public capital and economic growth. Annals of Regional Science 34 (3), 343-363.

Aubert, J.-E., 2006. Innovation systems in emerging and developing economies. In Blankley, W., Scerri, M., Molotja, N., Saloojee, I. (Eds.), Measuring Innovation in OECD and non-OECD Countries: Selected Seminar Papers. HSRC Press, Cape Town, S.A., pp. 21-42.

Audretsch, D., 2006. Entrepreneurship, Innovation and Economic Growth. Edward Elgar, Cheltenham.

Bhaduri, A., Steindl, J., 1983. The rise of monetarism as a social doctrine. Thames Papers in Political Economy, Autumn, 1-18.

Bloch, H., Courvisanos, J., Mangano, M., 2007. Investment in Process Innovation: Technological Obsolescence in Australian Manufacturing. Centre for Research in Applied Economics, Working Paper 2007-02, Curtin University of Technology, April 2007.

Brown, T.E., Ulijn, J. (Eds.), 2004. Innovation, Entrepreneurship and Culture. Edward Elgar, Cheltenham

Catley, R., McFarlane, B.J., 1981. Australian Capitalism in Boom and Depression. Alternative Publishing Cooperative, Chippendale, NSW.

Courvisanos, J., 1996. Investment Cycles in Capitalist Economies: A Kaleckian Behavioural Contribution. Edward Elgar, Cheltenham.

Courvisanos, J., 2005. A post-Keynesian innovation policy for sustainable development. International Journal of Environment, Workplace and Employment 1 (2) 187-202.

Courvisanos, J., 2007. The dynamics of innovation and investment, with application to Australia 1984-1998. In: Holt, R., Pressman, S. (Eds.), Empirical Post Keynesian Economics: Looking at the Real World. M. E Sharpe, Armonk, pp. 141-177.

Courvisanos, J., Verspagen, B., 2002. Innovation and investment in capitalis economies 1870-2000: Kaleckian dynamics and evolutionary life cycles. Investigación Económica LXII (242), 33-80.

Davis, S.J., Haltiwanger, J., Schuh, S., 1996. Small business and job creation: dissecting the myth and reassessing the facts. Small Business Economics 8 (4), 297-315.

Deeg, R., Jackson, G., 2007. Towards a more dynamic theory of capitalist variety. Socio-Economic Review 5 (1), 149-179.

Fontana, R., Guerzoni, M., 2008. Incentives and uncertainty: an empirical analysis of the impact of demand on innovation. Cambridge Journal of Economics 32 (5) 927-946.

Freeman, C., Perez, C., 1988. Structural crises of adjustment, business cycles and investment behaviour. In: Dosi, G., Freeman, C., Nelson, R., Silverberg, G. Soete, L. (Eds.), Technical Change and Economic Theory. Pinter, London, pp. 38-66.

Frey, B.S., 1978. Politico-economic models and cycles. Journal of Public Economics 9 (2), 203-220.

Galbraith, J.K., Darity Jr., W., 1994. Macroeconomics. Houghton Mifflin, Boston.

Goodwin, R.M., 1967. A growth cycle. In: Feinstein, C.H. (Ed.), Capitalism and Economic Growth. Cambridge University Press, Cambridge, pp. 54-58.

Goodwin, R.M., 1987. Macrodynamics. In: Goodwin, R.M., Punzo, L.F. (Eds.), The Dynamics of a Capitalist Economy: A Multi-sectoral Approach. Polity Press, Cambridge, pp. 1-160.

Goodwin, R.M., 1990. Chaotic Economic Dynamics. Clarendon Press, Oxford.

Hall, P.A., Soskice, D. (Eds.), 2001. Varieties of Capitalism: The Institutional Foundations of Comparative Advantage. Oxford University Press, Oxford.

Harcourt, G.C., 1997. Pay policy, accumulation and productivity. The Economic and Labour Relations Review 8 (1), 78-89.

Harcourt, G.C., 2006. The Structure of Post-Keynesian Economics: The Core Contributions of the Pioneers. Cambridge University Press, Cambridge.

Jones, A., 1987. The Art of War in the Western World. Harrap, London.

Kaldor, N., 1966. Causes of the Slow Rate of Growth in the United Kingdom. Cambridge University Press, Cambridge.

Kalecki, M., 1943. Political aspects of full employment. Political Quarterly 14 (4), 322-331. Reprinted in Osiatyński (1990), pp. 347-356. Abbreviated version in Kalecki (1971), pp. 138-145.

Kalecki, M., 1945. Full employment by stimulating private investment. Oxford Economic Papers, New Series 7, 83-92. Reprinted in Osiatyński (1990), pp. $377-$ 386.

Kalecki, M., 1954. Theory of Economic Dynamics: An Essay on Cyclical and Long-Run Changes in Capitalist Economy. Allen \& Unwin, London.

Kalecki, M., 1955. The impact of armaments on the business cycle after the Second World War, in: Osiatyński (1991), pp. 351-373.

Kalecki, M., 1967. Vietnam and US big business. Polityka 11 (3) (in Polish). Reprinted in English in Osiatyński (1997), pp. 292-297.

Kalecki, M., 1968. Trend and business cycle reconsidered. Economic Journal 78 (2), 263-276. Reprinted in Osiatyński (1991), pp. 435-450.

Kalecki, M., 1971. Selected Essays on the Dynamics of the Capitalist Economy, 1933-1970. University Press, Cambridge, Cambridge.

Kennedy, M.C., 1973. Employment policy: what went wrong? In: Robinson, J. (Ed.) After Keynes. Basil Blackwell, Oxford, pp. 71-87.

Keynes, J.M., 1936. The General Theory of Employment, Interest and Money. Macmillan, London.

Kleinknecht, A., Verspagen, B., 1990. Demand and innovation: Schmookler reexamined. Research Policy 19 (4), 387-394.
Kregel, J., 2008. Using Minsky's cushions of safety to analyse the crisis in the U.S. subprime mortgage market. International Journal of Political Economy 37 (1), $3-23$.

Laramie, A.J., Mair, D., 2007. Accounting for Changes in Corporate Profits: Implications for Tax Policy. Merrimack College, North Andover, MA, Mimeo.

Lowe, A., 1976. The Path of Economic Growth. Cambridge University Press, Cambridge.

Mair, D., Laramie, A.J., 2002. Full employment: gift horse or trojan horse? Review of Social Economy 60 (4), 567-593.

Malerbo, F., Orsenigo, L., 1997. Schumpeterian patterns of innovation. In: Archibugi, D., Michie, J. (Eds.), Technology, Globalisation and Economic Performance. Cambridge University Press, Cambridge, pp. 241-267.

Marx, K., 1954. Capital: A Critique of Political Economy, vol. 1. Progress Publishers, Moscow.

McColl, G., 2007. A measure of performance. Australian Innovation Festival. BRW, Melbourne, pp. 14-17.

Medio, A., 1987. Trade cycle. In: Eatwell, J., Milgate, M., Newman, P. (Eds.), The New Palgrave: A Dictionary of Economics, vol. 4. Macmillan, London, pp. 666-671.

Minsky, H., 1982. The financial-instability hypothesis: capitalist processes and the behavior of the economy. In: Kindleberger, C., Laffargue, J.-P. (Eds.), Manias, Panics and Crashes: A History of Financial Crisis. John Wiley \& Sons, Chichester, pp. 13-39.

Myers, S., Marquis, D.G., 1969. Successful Industrial Innovation. National Science Foundation, Washington.

OECD, 2005. Innovation Policy and Performance: A Cross-Country Comparison. Organisation for Economic Co-operation and Development, Paris.

OECD, 2006. OECD Reviews of Innovation Policy: Switzerland. Organisation for Economic Co-operation and Development, Paris.

OECD, 2008. OECD Reviews of Innovation Policy: China. Organisation for Economic Co-operation and Development, Paris.

O'Hara, P.A., 2007. Principles of institutional-evolutionary political economy: converging themes from the schools of heterodoxy. Journal of Economic Issues XLI (1), 1-42.

Osiatyński, J. (Ed.), 1990. Collected Works of Michał Kalecki, Volume I Capitalism: Business Cycles and Full Employment. Clarendon Press, Oxford.

Osiatyński, J. (Ed.), 1991. Collected Works of Michał Kalecki, Volume II Capitalism: Economic Dynamics. Clarendon Press, Oxford.

Osiatyński, J. (Ed.), 1997. Collected Works of Michał Kalecki, Volume VII Studies in Applied Economics: Miscellanea. Clarendon Press, Oxford.

Otto, G., Voss, G., 1994. Public capital and private sector productivity. Economic Record 70 (209), 121-132.

Parker, R., 2001. The myth of the entrepreneurial economy: employment and innovation in small firms. Work, Employment and Society 15 (2), 373-384.

Patel, P., Pavitt, K., 2000. National systems of innovation under strain: the internationalisation of corporate R\&D. In: Barrell, R., Mason, G., O'Mahony, M. (Eds.), Productivity, innovation and Economic Performance. Cambridge University Press, Cambridge, pp. 217-235.

Pavi, M., Vivarelli, M., 2007. Is demand-pull innovation equally important in different groups of firms? Cambridge Journal of Economics 31 (5), 691-710.

Perez, C., 2002. Technological Revolutions and Finance Capital: The Dynamics of Bubbles and Golden Ages. Edward Elgar, Cheltenham.

Porter, M., 1990. The Competitive Advantage of Nations. Free Press, New York.

Rothbarth, E., 1942. Review of Business Cycles by J.A. Schumpeter. The Economic Journal 52 (206/207), 223-229.

Salter, W.E.G., 1966. Productivity and Technical Change, second ed. Cambridge University Press, Cambridge.

Scherer, F.M., 1970. Industrial Market Structure and Economic Performance. Rand McNally \& Company, Chicago.

Schmookler, J., 1966. Invention and Economic Growth. Harvard University Press, Cambridge, MA.

Schumpeter, J.A., 1938. The Theory of Economic Development. Harvard University Press, Cambridge, MA.

Schumpeter, J.A., 1939. Business Cycles: A Theoretical, Historical and Statistical Analysis of the Capitalist Process, vols. I \& II. McGraw-Hill, New York.

Silverberg, G., Verspagen, B., 2003. Breaking the waves: a Poisson regression approach to Schumpeterian clustering of basic innovations. Cambridge Journal of Economics 27 (5), 671-693.

Stark, D., 2001. Ambiguous assets for uncertain environments: heterarchy in postsocialist firms. In: DiMaggio, P. (Ed.), The Twenty-First-Century Firm: Changing Economic Organization in International Perspective. Princeton University Press, Princeton, NJ, pp. 69-104.

Steindl, J., 1979. Stagnation theory and stagnation policy. Cambridge Journal of Economics 3 (1), 1-14.

Stilwell, F., 2002. Political Economy: The Contest of Ideas. Oxford University Press, Oxford.

Sylos-Labini, P., 1992. Capitalism, Socialism and Democracy and large-scale firms. In: Scherer, F.M., Perlman, M. (Eds.), Entrepreneurship, Technological Innovation, and Economic Growth: Studies in the Schumpeterian Tradition. The University of Michigan Press, Ann Arbor, pp. 55-64.

von Hippel, E., 2005. Democratizing Innovation. MIT Press, Boston.

White, G., 1999. Rethinking Kalecki on the trend and cycle. Review of Political Economy 11 (3), 341-353.

Zarnowitz, V., 1985. Recent work on business cycles in historical perspective: a review of theories and evidence. Journal of Economic Literature 23 (2),523-580. 